\title{
DNA Repair and Recombination Protein RAD54-Like
}

National Cancer Institute

\section{Source}

National Cancer Institute. DNA Repair and Recombination Protein RAD54-Like. NCI

Thesaurus. Code C21543.

DNA repair and recombination protein RAD54-like (747 aa, $\sim 84 \mathrm{kDa}$ ) is encoded by the human RAD54L gene. This protein plays a role in both DNA repair and mitotic recombination. 